\title{
New panel for ethical issues
}

\section{Washington}

FRUSTRATED by the US government's failure to provide the proper national forum for public debate, review and oversight of ethical issues in biomedical research, two medical organizations announced last week that they will establish a national advisory board to set ethical guidelines in reproductive and fetal tissue research.

The new 15-member board, to be known as the National Advisory Board on Ethics in Reproduction, will consist of lawyers, students of ethical issues, theologians, scientists and members of the public. The board aims to set guidelines in the sensitive areas of reproductive and fetal tissue research and will provide peer review of research proposals.

Because the board will have no legal authority, compliance with its recommendations will be voluntary. Financial support for its work will, to begin with, be provided by the two founding medical societies, the American College of Obstetricians and Gynaecologists (ACOG) and the American Fertility Society (AFS). Federal support for research involving in vitro fertilization and embryo transfer has not been available since 1980 , when the Reagan administration allowed the Ethical Advisory Board (EAB) to the Secretary of Health and Human Services (HHS) to lapse. The administration's position has not changed since 1980 .

A temporary ban on the federal funding of fetal tissue transplantation research in humans also took effect in March 1988, and was extended indefinitely in November 1989 by HHS Secretary Louis Sullivan. That decision, taken against the advice of an ad hoc NIH panel on the ethical issues of fetal transplantation, was based on the view that permitting such research would increase the incidence of abortions.

The new board will function most immediately in relation to privately funded research proposals, which are at present reviewed at a local level by institutional review boards, where they exist. Howard Jones, AFS spokesman and professor of obstetrics and gynaecology at the Eastern Virginia Medical School, says that local boards, when facing tough ethical questions, "sometimes feel they need consultation".

In a written statement, Kenneth Ryan, ACOG spokesman and chairman of the department of obstetrics and gynaecology at Harvard Medical School, argues that research on fetal tissue and reproductive technology is sustained and will continue "with or without government regulation", and that "the time is ripe for a private group to shoulder the task of setting stan- dards" to ensure that it is scientifically and ethically sound.

Predicatably, the new board was denounced by Douglas Johnson, legislative director of the National Right to Life Committee, who sees it as an attempt to erode public support for the pro-life policies that are in place. "All of these matters involve some pretty fundamental ethical concerns, and these should be decided through the democratic policy mechanisms which exist and not by a tiny clique of people who have an axe to grind", says Johnson.

The founding organizations hope that the members of the new board will be elected within six months.

Fetal tissue transplantation research offers promise for patients with neurological disorders such as Parkinson's and Alzheimer's disease. Several Parkinson's disease organizations and the Association of American Medical Colleges propose to challenge the legality of the administration's ban on the use of federal funds in a US federal district court.

A Chicago-based law firm has agreed to take on the case in the public interest. Dinah Tottenham Orr, executive director of the Parkinson's Disease Foundation, says that other disease groups may well follow suit.

Diane Gershon

\section{Nature appointment}

\section{London}

Barbara J. Culliton has been appointed deputy editor of Nature with effect from 1 February. Ms Culliton has been a member of the editorial staff of the AAAS journal Science since 1972, during which period she worked as news editor for the decade until 1989.

Ms Culliton has a distinguished record in science journalism, having served as president of the US National Association of Science Writers (1981-82) and of the US Council for the Advancement of Science Writing (1985-89). In 1989 she was elected a member of the Institute of Medicine, and is one of only three journalists so honoured.

The Editor of Nature, John Maddox, says that Ms Culliton's appointment will further and excellently strengthen Nature's position in the United States, which accounts for more than $\mathbf{4 0}$ per cent of the journal's international circulation, now in excess of 50,000 . He says that, apart from her plans to contribute to Nature, Ms Culliton has a number of exciting plans for strengthening the journal's service to the scientific community in the United States.

Ms Culliton will also be in administrative charge of Nature's US office in Washington, DC, where the journal's news-gathering is coordinated, and will be a senior partner in the evolution of editorial policy.

\section{London centre keeps Cray}

\section{London}

A row that had threatened the continued existence of the University of London Computer Centre (ULCC), one of only three British national centres for academic supercomputing, seems to have been resolved in a compromise that will transfer a smaller Amdahl machine from ULCC to the University of Manchester, where costs are lower.

The threat to ULCC arose last summer, when the Computer Board of the Department of Education and Science (DES) ruled that the cost of running the centre's Cray supercomputer and Amdahl machine, both of which are intended as national facilities, should be reduced from about $£ 3.3$ million to $£ 1.5$ million a year. This would have brought ULCC's running costs into line with the similar-sized Manchester centre.

The University of London rejected this plan, which would have saddled it with more of ULCC's running costs. This is already the practice at Manchester, where the national supercomputing facility is run at marginal cost alongside the local centre. But the court of the University of London seems to have argued successfully that circumstances in London are different. Each of London's colleges has its own computer centre, funded separately from ULCC.

ULCC staff had feared that both machines would be transferred - the Amdahl to Manchester and the Cray to the larger Atlas centre at the Science and Engineering Research Council's Rutherford Appleton Laboratory.

Under the deal negotiated between the Computer Board and the university, ULCC's Cray-XMP will be replaced by a new machine, probably a Cray-YMP, which has a larger memory and is cheaper to run. Fewer than 20 ULCC staff are required to run the scalar computing service provided on the Amdahl, and the university expects that there will be no forced redundancies. The slimmed-down ULCC will cost about $£ 2$ million a year.

The University of London is pleased with the new arrangement, but British academics will still be left with poorer provision for supercomputing than many of their European colleagues. France and Italy each have almost twice the academic supercomputing power of Britain, and most German Länder have their own academic supercomputing centres supported in part with their own funds.

Peter Aldhous 